\title{
Sciendo
}

\author{
DOI: $10.2478 /$ jolace-2020-0012

\section{The French Language Olympiad: Promoting language and culture learning}

\author{
Merilyn Meristo \\ Tallinn University, Estonia \\ merilyn.meristo@tlu.ee
}

\begin{abstract}
The aim of this paper is to shed light on promoting teaching and learning the French language and culture through the Olympiad, initiated by a group of practitioners in a community of practice. What makes this Olympiad rather unique is its main focus on cultural knowledge combining it with linguistic aspects. The Olympiad takes place in four different categories taking into account students' age and prior experience in learning French (e.g. first or second foreign language). In addition, the regional round is organised in Moodle enabling more participants to take part and the national one in situ, at the University of Tallinn. Since the first Olympiad in 2014, the number of competitors has increased and both, private and municipality funded (public) schools participate. The paper provides a detailed overview of the olympiad process: how it was initiated and how it is annually run as well as a description of challenges faced by the organisers.
\end{abstract}

Keywords: French language and culture, language olympiad, language competition, community of practice, action research

Presumably, it was the first Olympiad in Linguistics in 1965 at Moscow State University that inspired the followers to create olympiads in languages (Derzhanski \& Payne, 2010). First, the East-European countries, followed several decades later by the Western world, initiated different olympiads adapting their own format and criteria (Hudson \& Sheldon, 2013). However, in 1960 there was already a foreign language competition of spoken language at national level held in Estonia for students of English and German (Rannap, 2014).

The primary purpose of organising olympiads and subject competitions in almost all the subjects taught at school is to offer talented students a challenge to show their acquired deep and wide knowledge in a particular subject. Nevertheless, there is another and not less important goal, which is popularising and promoting awareness of and interest towards that particular subject to a larger audience of students. In addition, olympiads provide different alternatives from national or school exams which are mainly in line with the expected outcome of the national curriculum and tests, while olympiads, instead, suggest more 
intellectual challenges (Hudson \& Sheldon, 2013). The broader aim of olympiads is related to universities who search for outstanding students and provide the winners with a possibility for a smooth and direct enrolment (Estival et al., 2014). The French Language Olympiad (FLO) targets to cover all above mentioned aims.

\section{Community of Practice}

Driven by well-established examples of other olympiads of languages in Estonia, a small group of enthusiasts from Tallinn University and from the Association of French Language Teachers, set a goal to create a similar olympiad in their field. Willingness and readiness to initiate, bring about and implement changes and innovative solutions into educational landscape is an evidence of teacher agency (MacLellan, 2017; Orland-Barak, 2017; Leijen et. al., 2019). Moreover, this kind of a bottom-up initiative fits well into the concept of a community of practice (Lave \& Wenger, 1991), which is described by three key components: a shared domain of interest (promoting French language and culture); a practice (in the Estonian context a relatively small ensemble of practitioners, i.e. teachers and researchers of French); and a community (an active and systematic interaction between practitioners). The development of an olympiad assumes a cyclical approach during which several evaluation and correction phases are included in order to improve the final outcome (background information, planning, implementation, evaluation, correction, reflection). Therefore, a combination of the principles for cultivating a community of practice and action research design was considered appropriate to use (Drummond \& Themessl-Huver, 2007; Wenger et al., 2002). Although, the present case is not a typical action research where the focus is on finding a practical solution to an existing problem as the lack of an olympiad is not regarded as a true problem. However, as the methodology of action research enables to carry out activities to implement changes to improve not only teacher's own professional development, but also in a larger scale, organise collaboration (Levin \& Greenwood, 2001; McAteer, 2013), the elements of action research combined with a 7-principles model ${ }^{1}$ of the community of practice proposed by Wenger and her colleagues (2002) led us to the following design: Inviting the members of community to a dialogue; Planning with focusing on value; Implementation; EvaluationCorrection; Creating a stable rhythm for an olympiad; Reflection.

1 1. Design for evolution. 2. Open a dialogue between inside and outside perspectives. 3. Invite different levels of participation. 4. Develop both public and private community spaces. 5. Focus on value. 6. Combine familiarity and excitement. 7. Create a rhythm for the community (Wenger, McDermott \& Snyder, 2002). 


\section{Background information: Estonian context}

Annually there are olympiads in about 20 school subjects, with more than 10,000 students participating in regional rounds and 1,000 in the national round (Teaduskool). The FLO is a relative newcomer to the scene of Estonian olympiads, having only officially started in the academic year 2014/2015, whilst the majority date back several decades to the period of the Soviet era: in the 1970s and 1980s. In addition to olympiads there is a myriad of subject competitions, organised and held mostly regionally, which target students of all ages as olympiads may be available only for a certain age group (e.g. upper-secondary school). It is important to mention that olympiads in Estonia are supported by the Estonian Ministry of Education and Research and organised by universities or associations of school subjects.

The first olympiads in foreign languages in Estonia, such as English, German and Russian took place in the 1960 and have continued without interruption. However, the format of the olympiads of above mentioned languages differ from each other and has changed during the course of time. There are no fixed standards. Some enhance communicative skills, some linguistic aspects, and some promote research skills.

In Estonia, French as a foreign language (FL) has different statuses at school, such as FL1, FL2 or FL3. In total there are 4,144 learners ${ }^{2}$ of French at all school levels, which is 2,2\% compared to English (62,5\%), Russian (27,5\%), German (6\%) and other languages $(1,8 \%)$. Learning FL1 starts from the age of 8-9 years at elementary school, FL2 usually starts at basic school (age 11-12 years) and FL3 at upper-secondary school (age 16-17 years), but there are exceptions where FL3 starts at lower-secondary school (age 13-14 years). It is equally important to mention that in Estonia the school leader has a lot of autonomy to decide the school's curriculum - there is the national curriculum to follow but the school can add a certain number of classes of any subject per week and it is up to the school's priorities to decide which subjects are given additional classes, and many schools have chosen foreign languages. That explains why the number of French classes per week or the beginning of FL2 and/or FL3 tuition may vary according to the school. Below, a short description of different statuses of French at school is given as this information is relevant to understand the concept of FLO.

\section{French as the first foreign language}

French as FL1 is learned by 1,153 students, compared to English with 10,1214 students (95,8\%), German 2,263 (2,1\%) and Russian 1,057 (1\%) students. There are 5 comprehensive schools in Estonia where French is taught as the first foreign

\footnotetext{
${ }^{2}$ Here and further, the data regard academic school year 2019/2020 and are derived from statistical database Haridussilm.
} 
language since the first or second year of the elementary school. In most schools FL1 is given 3 to 4 classes of 45 minutes duration per week. At the end of lowersecondary school (age 15-16 years) FL1 learners are expected to have reached B1 level (CEFR ${ }^{3}$ ) and at the end of upper-secondary school B2 level.

\section{French as the second or third foreign language}

There are 2,991 students from approximately 40 comprehensive schools where French is FL2 or FL3. Classes of 45 minutes duration per week vary between 2 to 4 . In addition, FL3 may be offered as an optional course at upper-secondary school or as a compulsory one with a choice between several foreign languages. At the end of lower-secondary school FL2/3 learners are expected to have reached A2/A1 level and at the end of upper-secondary school B1/A2 level.

Besides French taught at school, Institut Français and language schools offer French language courses, which according to the information on respective websites, are popular. That explains why every year there are certain participants at the FLO who do not study French at school (during the registration to the FLO that information is requested) but independently, meaning outside the classroom at language schools or with private teachers.

\section{Planning with focusing on value: Initiation of FLO}

First phase

In May 2014, 115 teachers of French (nearly the whole population, some contact email addresses were undetectable or erratic) were contacted through emails to invite them to participate in a roundtable discussion which aimed to answer 2 questions: Is there a need and an interest towards conducting a French language olympiad? What would be the format of the olympiad, based on teachers' expectations? 30 teachers responded expressing their support, welcoming the idea and encouraging further development.

In June 2014, 15 teachers eventually participated in the first roundtable, held at the premises of Tallinn University. The first question received quickly and unanimously a firm positive answer. The second question about conceptualising the format of the olympiad saw a lively discussion. Firstly, the formats of existing olympiads in different languages were analysed and the result revealed that in most cases those olympiads at regional level check participant's linguistic skills and at national level the participant has to express both linguistic and oral skills, quite often in a similar manner as exams do. Secondly, a clear goal was set before deciding about the format: to promote the French language and culture and not to

${ }^{3}$ CEFR: Common European Framework of Reference for Languages 
replicate the format of exams as the French national language exam $\mathrm{DELF}^{4}$ had already been successfully implemented and was popular among students (Innove). Thirdly, the first roundtable meeting decided that in order to promote the language and culture an online platform should be used at regional level to enable broad participation and facilitate the evaluation. Fourthly, organisational tasks were divided, a timetable was set, and the next meeting was fixed for August 2014. Finally, the roundtable decided on the format of the first Olympiad that is introduced in the following sub-chapter.

\section{Format of FLO}

The first Olympiad in $2014 / 2015$ as a pilot version would be organised only for lower-secondary school students (age13-16) in two categories: for students of FL1, corresponding to the level of B1 (CEFR) and for students of FL2/3 respectively to level A2/A1 (CEFR).

The topic would be a French speaking region of a French speaking country and the tasks would only be about cultural matters (traditions, history, geographical facts, monuments and sightseeing, architecture, celebrities, literature, regional gastronomy).

The selection of participants for the regional round would be decided by the schools during December 2014, the number of participants would not be limited for both categories of the regional round.

The regional round would take place in January 2015 and the tasks would include multiple choice questions. Moodle as a platform, that universities and schools are familiar with, was chosen for the regional round. Moodle would be open for participants during 60 minutes on a previously announced date and time and the schools of the participants must guarantee a space equipped with computers and the surveillance as no extraneous materials would be allowed to be used.

The national round would take place in February 2015 at Tallinn University and the participants (the best performers of the regional round) would show their oral skills: first they would have a lottery draw to find out their topic on a specific geographical place (village, town), then they would have 90 minutes to prepare for the presentation called "Guide touristique" about that particular geographical place; internet and all technical devices would be allowed (computers) during the preparation, and finally they would have 3-5 minutes for the oral presentation with visual (computer screen) help in front of 3 members of the jury.

${ }^{4}$ DELF: Diplôme d'études en langue française 


\section{Second phase}

In August 2014, five people gathered for the next meeting to discuss the organisational details at the premises of the university (a representative from the university, a representative from the Association of French Language Teachers, a native teacher of French and two non-native teachers). The others withdrew claiming to have too many duties already at work.

The following was agreed upon. The topic of the first FLO would be 'AlsaceLorraine'. The formulation of the Multiple Choice Questions should take into account the participants level of French, i.e. the formulation would be as simple as possible. A clear step-by-step 'Instructions' would be compiled and provided to schools where French is taught to invite their learners of French to take part in the new olympiad as well as to explain the procedure and the registration. Teachers who are teaching at schools with potential participants should not participate in the preparation and creation of the bank of questions in order to guarantee the confidentiality of questions. A fixed timetable together with detailed duties and people responsible for each duty was set. It was decided that the number of students shortlisted at the regional round to be invited to the national round remained to be decided after the regional round as it was unpredictable how many participants might take part. At the national round, the students with the first three best results of both categories would be awarded as well as their supervisors. All participants would receive an Honorary Certificate of participation and their supervisors would receive a Letter of Gratitude.

\section{Implementation of the FLO}

In December 2014 the bank of questions for the first FLO was ready. Only one of the organisers had access to all the questions and that person eventually chose 28 questions for both categories. Table 1 displays examples of the questions of the first FLO according to the categories.

On January $2^{\text {th }} 2015$ between 10-11am the regional round of FLO took place using Moodle. There were 115 participants altogether $\left(90\right.$ in the $1^{\text {st }}$ category and 25 in the $2^{\text {nd }}$ category) from 5 different schools from three different towns in Estonia. No technical problems occurred, though the Moodle support team at the university were ready if needed.

On February $16^{\text {th }}$ at 10 am the national round was held at Tallinn University. The jury was composed of three people. Based on the results of the regional round eight students were invited to the national round in the $1^{\text {st }}$ category and six in the $2^{\text {nd }}$ category. Eventually six students from the $1^{\text {st }}$ category and only two students from the $2^{\text {nd }}$ category participated. After the oral presentations a closing ceremony took place where awards were given to the winners. It should also be mentioned that all the participants received a warm meal and refreshments were available all day long. 


\begin{tabular}{|c|c|c|c|c|}
\hline $\begin{array}{l}\text { Categories } \\
\text { of the } \\
\text { olympiad }\end{array}$ & $\begin{array}{l}\text { School } \\
\text { stage }\end{array}$ & $\begin{array}{l}\text { FL } \\
\text { status }\end{array}$ & $\begin{array}{l}\text { CEFR } \\
\text {. }\end{array}$ & $\begin{array}{l}\text { Examples of questions of regional } \\
\text { round }\end{array}$ \\
\hline $\begin{array}{l}1^{\text {st }} \\
\text { category }\end{array}$ & $\begin{array}{l}\text { Lower- } \\
\text { secondary } \\
\text { school } \\
\text { (age } 14- \\
16 \text { years) }\end{array}$ & FL1 & B1 & $\begin{array}{l}\text { - La bataille de Verdun fut une bataille } \\
\text { de: } \\
\text { a) Guerre de 1870-1871; b) Guerre de } \\
\text { 1914-1918; c) Guerre de 1939-1945; } \\
\text { - Quelle institution de l'UE siège à } \\
\text { Strasbourg? } \\
\text { a) Médiateur européen (ombudsman } \\
\text { européen); b) Cour de Justice de l'UE; c) } \\
\text { Banque centrale européenne; d) Europol; } \\
\text { - Quel ingrédient n'appartient pas à la } \\
\text { recette de fameuse «Quiche lorraine } \\
\text { „? } \\
\text { a) Lardon fumé; b) Fromage; c) Oeufs; d) } \\
\text { Tomate; } \\
\text { - Parmi les expressions suivantes } \\
\text { laquelle signifie "Oui » en lorrain? } \\
\text { a) Jo; b) Ui; c) Ja; } \\
\text { - L'Alsace est la région d'origine de la } \\
\text { dynastie: } \\
\text { a) des Capétiens; b) des Bourbons; c) des } \\
\text { Habsbourg }\end{array}$ \\
\hline $\begin{array}{l}2^{\text {nd }} \\
\text { category }\end{array}$ & $\begin{array}{l}\text { Lower- } \\
\text { secondary } \\
\text { school } \\
\text { (age 14- } \\
16 \text { years) }\end{array}$ & FL2/3 & $\mathrm{A} 2 / \mathrm{A} 1$ & $\begin{array}{l}\text { - Comment on appelle la brioche } \\
\text { alsacienne? } \\
\text { a) Gâche; b) Pogne; c) Kougelhoff; d) } \\
\text { Panettone; } \\
\text { - Quel est le sommet le plus haut de } \\
\text { l'Alsace-Lorraine? } \\
\text { a) Puy de Sancy; b) Crêt de la Neige; c) } \\
\text { Grand Ballon; d) Vignemale; } \\
\text { - La langue alsacienne est un dialecte } \\
\text { de la langue: } \\
\text { a) française; b) allemande; c) italienne; } \\
\text { d) flamande; } \\
\text { - Qu'est-ce qu'une «Mirabelle»? } \\
\text { a) Un joli prénom alsacien; b) Un joli } \\
\text { village en Lorraine; c) Une marque de } \\
\text { biscuit; d) Une sorte de prune }\end{array}$ \\
\hline
\end{tabular}

Tab. 1: Examples of the questions of the first FLO in 2014/15. 


\section{Evaluation and corrections}

In March 2015, the organising team had another meeting to evaluate the success of the first FLO and detect the areas that needed to be improved. Unanimously it was agreed that the first and pilot FLO had succeeded well and that the organisers would proceed with preparations for upper-secondary school level to be included in the future olympiads. To clarify the final categories, Table 2 displays the set of categories which is still used.

\begin{tabular}{|l|l|l|l|}
\hline $\begin{array}{l}\text { Categories of the } \\
\text { Olympiad }\end{array}$ & School stage & FL status & $\begin{array}{l}\text { CEFR } \\
\text { correspondence }\end{array}$ \\
\hline $1^{\text {st }}$ category & $\begin{array}{l}\text { Lower-secondary school } \\
\text { (age 14-16) }\end{array}$ & FL1 & B1 \\
\hline $2^{\text {nd }}$ category & $\begin{array}{l}\text { Lower-secondary school } \\
\text { (age 14-16) }\end{array}$ & FL2/3 & A2/A1 \\
\hline $3^{\text {rd }}$ category & $\begin{array}{l}\text { Upper-secondary school } \\
\text { (age 16-19) }\end{array}$ & FL1 & B2 \\
\hline $4^{\text {th }}$ category & $\begin{array}{l}\text { Upper-secondary school } \\
\text { (age 16-19) }\end{array}$ & FL2/3 & A2/A1 \\
\hline
\end{tabular}

Tab. 2: The categories of the FLO.

We as organisers could not have predicted the number of participants and therefore hoped for the best. 115 students to our positive surprise from 5 different schools participated in the first FLO. Table 3 shows the dynamics in numbers of participants and schools from 2014/15 to the present.

\begin{tabular}{|l|l|l|l|l|l|l|}
\hline $\begin{array}{c}\text { Years } \\
\text { Categories }\end{array}$ & $2014 / 15$ & $2015 / 16$ & $2016 / 17$ & $2017 / 18$ & $2018 / 19$ & $2019 / 20$ \\
\hline $1^{\text {st }}$ category & 90 & 13 & 18 & 19 & 24 & 30 \\
\hline $2^{\text {nd }}$ category & 25 & 8 & 33 & 32 & 37 & 26 \\
\hline $3^{\text {rd }}$ category & - & 19 & 23 & 18 & 26 & 22 \\
\hline $4^{\text {th }}$ category & - & 18 & 44 & 49 & 55 & 58 \\
\hline Total $\boldsymbol{N}$ & $\mathbf{1 1 5}$ & $\mathbf{6 8}$ & $\mathbf{1 1 8}$ & $\mathbf{1 1 8}$ & $\mathbf{1 4 2}$ & $\mathbf{1 3 6}$ \\
\hline Schools & 6 & 8 & 12 & 17 & 16 & 20 \\
\hline
\end{tabular}

Tab. 3: The number of participants and schools across years.

During the meeting the following changes after deliberation were agreed upon. There was no limit for participants in the national round in Moodle. However, the analysis of the results showed that more than half of the participants received a success rate below $50 \%$ of correct answers. The feedback from the supervisors indicated that there were many who just wanted to try. We found that those who participated unprepared were not taking the Olympiad seriously and the aim of learning more deeply about French culture was not accomplished. Therefore, the 
limit of 6 students per one category from each school was set in 2015/16. We had to correct the number of participants one more time after the second national round following the suggestions from the supervisors: we increased the limit of participants per category to 10 students and so it remains. Further analysis of the results after each Olympiad has confirmed that the average success rate has not fallen below 50\%. The average success rate in all categories stays between 55$67 \%$. No participant has ever reached a maximum score success, the best success rates reach between $78-85 \%$ and the lowest remain between $20-35 \%$. The low number of participants of the first national round, i.e. the oral presentations, could be explained (based on the feedback of the supervisors) by the fear of the unknown and low self-confidence. However, the first pioneers spread their positive experience among their school fellows and this problem has not occurred since. All invitees have taken part in the national round unless they have fallen ill and have notified the organisers. In addition, our jury members are always very supportive no matter what the participant's level of oral expression might be. We consider the positive feeling and well-being of participants of utmost importance.

Questions regarding cultural and geographical matters were welcomed by students and supervisors. Especially the idea that every year one region of a French-speaking country is in focus. The different regions of France as topics of the FLO have been so far: Alsace-Lorraine, Normandie, Bretagne, Pays de la Loire, Provence and Occitanie. Future plans include Quebec, Wallonie, Suisse romande and France d'outre-mer. Although, both students and teachers admitted that it was hard to prepare for the Olympiad as so many areas had to be covered. We feel that this was exactly what we had targeted in the first place: to familiarise students with a broad spectrum of topics. Table 4 shows random examples of the questions of the regional round and the oral topics of the national round from different years. In addition, as an improvement after the first FLO, photos images were added to illustrate some questions and make the visual side more interesting. Some questions asked to recognise a certain object in the picture (e.g. the famous cathedral of Rouen) and the options were given verbatim; while another question asked to recognise a certain object and the options given were photos (e.g. the respondent had to recognise the famous aqueduct 'Pont du Gard' among 3 other bridges).

Another specification that we made after the first Olympiad was a strong recommendation for students, who come from a bilingual setting or have lived or studied in a French speaking country, to participate in the category of FL1, irrespective of the age group. This issue emerged among supervisors who did not know how to advise their students with a higher level of language, though officially belonging to the category of FL2/3. Those students themselves were ready for more challenging tasks than their category would have offered. Moreover, it 
seemed unfair as they were in a more advantageous situation compared to FL2/3 students who had not been naturally exposed to French.

\begin{tabular}{|c|c|c|}
\hline $\begin{array}{l}\text { Categories } \\
\text { of FLO }\end{array}$ & $\begin{array}{l}\text { Examples of questions of regional } \\
\text { round }\end{array}$ & $\begin{array}{l}\text { Examples of oral topics of } \\
\text { national round }\end{array}$ \\
\hline $1^{\text {st }}$ category & $\begin{array}{l}\text { Quel constructeur de transport } \\
\text { européen a-t-il son siège en } \\
\text { Occitanie? } \\
\text { a) Airbus; b) Air France; c) Renault; } \\
\text { d) Peugeot. }\end{array}$ & $\begin{array}{l}\text { Info touristique: Les sites } \\
\text { préhistoriques en Provence } \\
\text { Info touristique: L'été indien } \\
\text { en Bretagne }\end{array}$ \\
\hline $2^{\text {nd }}$ category & $\begin{array}{l}\text { Sur quelle photo peut-on voir la } \\
\text { ville de Carcassonne? (the choice of } \\
4 \text { photos) }\end{array}$ & $\begin{array}{l}\text { Info touristique: Que faire et } \\
\text { que voir à Saint-Malo } \\
\text { Info touristique: Que faire et } \\
\text { que voir à Strasbourg }\end{array}$ \\
\hline $3^{\text {rd }}$ category & $\begin{array}{l}\text { Qui a fait construire le château de } \\
\text { Chambord? } \\
\text { a) François Ier; b) Louis XI; c) Charles } \\
\text { V; d) Henri II; } \\
\text { En quelle année a été construit le } \\
\text { Pont du Gard? } \\
\quad \text { a) environ } 1000 \text { ans avant J.- } \\
\text { C.; b) environ } 200 \text { ans avant J.-C.; c) } \\
\text { environ } 50 \text { ans après J.-C.; d) environ } \\
1000 \text { ans après J.-C. }\end{array}$ & $\begin{array}{l}\text { Info touristique: Les jardins } \\
\text { botaniques de l'Occitanie } \\
\text { Info touristique : Le tourisme } \\
\text { durable en Provence }\end{array}$ \\
\hline $4^{\text {th }}$ category & $\begin{array}{l}\text { Quel festival a lieu à Montpellier } \\
\text { tous les ans? } \\
\text { a) Fête du Citron; b) La Fête de l'Eau; } \\
\text { c) Le Festival de Danses Historiques; } \\
\text { d) Le Festival International des } \\
\text { Sports Extrêmes. }\end{array}$ & $\begin{array}{l}\text { Info touristique: Que faire et } \\
\text { que voir à Orléans } \\
\text { Info touristique: Que faire et } \\
\text { que voir à Nice }\end{array}$ \\
\hline
\end{tabular}

Tab. 4: Random examples of MCQ of the regional round and oral topics of the national round.

Based on the feedback from the teachers after the first FLO linguistic tasks were added. We maintained the emphasis on cultural aspects, yet 2-3 linguistic tasks were provided. Table 5 demonstrates the different types of linguistic tasks for each category used since the first FLO. As for the task to fill in the gaps of a text, the topic of the text has always been related to the general topic of that particular Olympiad, i.e. a region of France. The length of the texts varies between 80 ( $2^{\text {nd }}$ category) to 200 words ( $3^{\text {rd }}$ category). Although the linguistic tasks are answered in Moodle, marking them is by hand to ensure that all possible answers are individually assessed as, for example, filling in a cloze procedure may have too many correct 
options to insert into Moodle for autocorrection. Marking is always conducted by a native language teacher and one teacher marks the whole category, again to guarantee an assessment of the same style, i.e. the teacher may give from 0.25 points to 1.0 point to a correct answer as long as the marking is consistent.

\begin{tabular}{|c|c|}
\hline $\begin{array}{l}\text { Categories } \\
\text { of FLO }\end{array}$ & Linguistic tasks \\
\hline $1^{\text {st }}$ category & $\begin{array}{l}\text { Writing a short text: Donnez trois raisons de passer les vacances au } \\
\text { Centre-Val de Loire! } \\
\text { Paraphrasing: Il a toujours la tête dans les nuages. } \\
\text { Filling in the gaps: respondents have to guess missing words based on } \\
\text { the context; the choice of words is given with } 3 \text { extra words. }\end{array}$ \\
\hline $2^{\text {nd }}$ category & $\begin{array}{l}\text { Writing a short text: Présentez-vous ! Éssayez d'utiliser des verbes et des } \\
\text { adjectifs différents. } 60-100 \text { mots } \\
\text { Paraphrasing the underlined part: Il faut acheter du pain. } \\
\text { Filling in the gaps: respondents have to guess missing words based on } \\
\text { the context; the choice of words is given with } 2 \text { extra words. }\end{array}$ \\
\hline $3^{\text {rd }}$ category & $\begin{array}{l}\text { Paraphrasing: Nous ne savons rien faire de nos dix doigts. } \\
\text { Choosing the correct form: La vaccination des_ est un sujet de } \\
\text { discussion animée. a) nouveaux-né; b)nouveaux-nés; c) nouveau-nés. } \\
\text { Cloze procedure: respondents have to guess missing words based on } \\
\text { the context; a choice of words is not provided. }\end{array}$ \\
\hline $4^{\text {th }}$ category & $\begin{array}{l}\text { Filling in the gaps with a choice of } 2-3 \text { extras words is given; } \\
\text { Paraphrasing: Il tombe de la pluie. }\end{array}$ \\
\hline
\end{tabular}

Tab. 5: Examples of linguistic tasks of FLO.

\section{Creating a stable rhythm for the Olympiad}

The first FLO in 2014/15 encouraged us to continue. During the six years we have succeeded in creating a stable rhythm, i.e. the regional round takes place in January, leaving the schools enough time to select the participants in NovemberDecember, and the national round takes place in March. The next year's topic is announced as the last information at the closing and awarding ceremony of the national round. The exact dates of the following Olympiad are also announced on the website after the national round has taken place, allowing the students and supervisors to prepare at least eight months prior to the following national round.

\section{Reflection and conclusion}

The successful experience of the first and pilot version of FLO was possible mostly thanks to the enthusiasm of the practitioners of the community of practice. The organisers were and still are motivated by the moral support provided by the schoolteachers. Moreover, during the 6 years of the existence of FLO it has been very encouraging to see the same students participating over several years: those 
who have been successful in lower-secondary school categories are often to be met again in upper-secondary categories. However, the organisers still put a lot of effort into promoting the FLO. There are still many schools where French is taught, but whose students have not yet participated in an olympiad. So called Informative days have taken place in different towns for teachers and students who have been interested in the FLO but have not yet had the confidence to compete. Using PowerPoint slides and screenshot examples from Moodle all possible questions and nuances (linguistic concepts) have been discussed and explained.

The importance and value of FLO can be discussed at several levels. At local level: in most schools, teachers are encouraged to guide their students towards different competitions and olympiads. The FLO is no exception. Furthermore, many schools publish the FLO achievements of their students on their schools' websites. Some schools have featured in the local press after results of competitions have been published. In addition, Regional Departments of Education acknowledge and praise the best students in different ways. At community level: there is a lot of direct communication between the organisers and supervisors / potential future supervisors. At least we, as organisers have always endeavoured to minimise the barrier and promote collaboration within our community of practice by listening to the practitioners' voice and taking into account their input and recommendations. Besides the annual celebrations of Francophonie in March and Bastille Day on July $14^{\text {th }}$ the FLO unites practitioners in its own competitive manner. At national level: the FLO enables the best students to excel and compare themselves to other competitors. We have initiated the French Language Olympiad of the Baltic Countries in collaboration with Latvian and Lithuanian colleagues and the first Olympiad took place in March 2019 in Tallinn allowing the best five students of each country (of the $3^{\text {rd }}$ category as the only category comparable in all three countries) to take further challenges and hold a debate with each other on actual topics in the society.

The feedback from teachers shows clearly that there are those who systematically and methodologically prepare their students for FLO and we could not be happier as the first and foremost goal of the FLO is to promote the French language and culture. Namely cultural elements add value to the whole process and lead students beyond course books. The preparation of students does not usually take place individually because the time resources cannot allow it, but in the form of activities where the whole French learning group is engaged it is a beneficial situation for all students. One can neither call it a washback effect often related to drilling for exams, as the speaking competence which has been set in focus is universally important and is not associated only to the olympiads. We also have feedback from two Estonian universities (Tallinn and Tartu) where French is 
taught as a major, that Olympiad winners have used the possibility to enrol smoothly.

Studying the phenomenon of olympiads offers a wide range of directions for future research. Starting from the statistical analyses of questions to the analyses of supervisors' and students' expectations and attitudes.

\section{References}

Derzhanski, I., \& Payne, T. (2010). The Linguistics Olympiads-Academic competitions in linguistics for secondary school students. Cambridge: Cambridge University Press. https://doi.org/10.1017/CB09780511770791

Drummond, J. S., \& Themessl-Huver, M. (2007). The cyclical process of action research. Action Research, 5(4), 430-448.

Estival, D., Bow, C. P., Henderson, J., Kelly, B. F., Laughren, M., Mayer, E., \& Vaughan, J. (2014). Australia Loves Language Puzzles: The Australian Computational and Linguistics Olympiad (OzCLO). Linguistics and Language Compass, 8(12), 659670. https://doi.org/10.1111/lnc3.12096

Haridussilm (s.a.). Foreign language learning database. Retrieved from: http://www.haridussilm.ee/?leht=alus_yld_6

Hudson, R., \& Sheldon, N. (2013). Linguistics at School: The UK Linguistics Olympiad. Language and Linguistics Compass, 7(2), 91-104. https://doi.org/10.1111/lnc3.12010

Innove (s.a.). Eksamid ja testid [Exams and tests]. Retrieved from: https://www.innove.ee/eksamid-ja-testid/rahvusvahelisedvoorkeeleeksamid/delf-scolaire/

Lave, J., \& Wenger, E. (1991). Situated learning. Legitimate peripheral participation. Cambridge: University of Cambridge Press.

Leijen, Ä., Pedaste, M., \& Lepp, L. (2019). Teacher Agency Following the Ecological Model: How it is Achieved and How it Could Be Strengthened by Different Types of Reflection. British Journal of Educational Studies,

DOI: $10.1080 / 00071005.2019 .1672855$

Levin, M., Greenwood, D. (2001). Pragmatic action research and the struggle to transform universities into learning communities. In Reason, P. \& Bradbury, H. (Eds.), Handbook of action research: Participative inquiry and practice (pp. 103113). Thousand Oaks, CA: SAGE.

MacLellan, E. (2017). Shaping Agency through Theorizing and Practicing Teaching in Teacher Education. In Education, T., Clandinin, D. J., \& Husu, J. (Eds.), The SAGE Handbook of Research on Teacher Education (Los Angles, Sage), 253-268. McAteer, M. (2013). Action Research in Education. Sage. DOI: http://dx.doi.org/10.4135/9781473913967.n4 
McEown, M. S., \& Oga-Baldwin, W. L. Q. (2019). Self-determination for all language learners: New applications for formal language education. System. Doi:10.1016/j.system.2019.102124

Orland-Barak, L. (2017) Learning teacher agency. In Education, T., Clandinin. D. J., \& Husu, J. (Eds.), The SAGE Handbook of Research on Teacher Education (pp. 247-252). Los Angles: Sage.

Rannap, H. (2014). Eesti kooli ja pedagoogika kronloogia [The Chronology of Estonian school and pedagogics]. Ministry of Education and Research. Retrieved.

from: https://www.hm.ee/sites/default/files/eesti_kooli_ja_pedagoogika_kronoloo gia.pdf

Teaduskool (s.a.). Eesti olümpiaadid. Retrieved from: https://www.teaduskool.ut.ee/et/olumpiaadid/eesti-olumpiaadid Wenger, E., McDermott, R., Snyder, W. M. (2002). A guide to managing knowledge: Cultivating communities of practice. Boston, MA: Harvard Business School Press.

\section{Contact}

Merilyn Meristo

Tallinn University

School of Humanities

Narva mnt 25

Tallinn 10120

Estonia

merilyn.meristo@tlu.ee 